\title{
Expression and Physiological Actions of Cholecystokinin in Rat Taste Receptor Cells
}

\author{
Scott Herness,, ${ }^{1,2}$ Fang-li Zhao, ${ }^{1}$ Shao-gang Lu, ${ }^{1}$ Namik Kaya, ${ }^{1}$ and Tiansheng Shen ${ }^{1}$ \\ ${ }^{1}$ Department of Oral Biology, College of Dentistry, and '2Department of Neuroscience, College of Medicine, Ohio State \\ University, Columbus, Ohio 43210
}

Gustatory perception arises not only from intracellular transduction cascades within taste receptor cells but also from cell-to-cell communication among the cells of the taste bud. This study presents novel data demonstrating that the brain-gut peptide cholecystokinin (CCK) is expressed in subsets of taste receptor cells, and that it may play a signaling role unknown previously within the taste bud. Immunocytochemistry revealed positively stained subsets of cells within taste buds throughout the oral cavity. These cells typically displayed round nuclei with full processes, similar to those classified as light cells. Peptide expression was verified using nested PCR on template CDNA derived from mRNA extracted from isolated posterior taste buds. Multiple physiological actions of cholecystokinin on taste receptor cells were observed. An outward potassium current, recorded with the patch-clamp technique, was inhibited by exogenous application of sulfated cholecystokinin octapeptide in a reversible and concentration-dependent manner. Pharmacological analysis suggests that this inhibition is mediated by CCK-A receptors and involves PKC phosphorylation. An inwardly rectifying potassium current, typically invariant to stimulation, was also inhibited by cholecystokinin. Additionally, exogenous cholecystokinin was effective in elevating intracellular calcium as measured by ratiometric techniques with the calcium-sensitive dye fura-2. Pharmacology similarly demonstrated that these calcium elevations were mediated by CCK-A receptors and were dependent on intracellular calcium stores. Collectively, these observations suggest a newly discovered role for peptide neuromodulation in the peripheral processing of taste information.

Key words: sensory transduction; cholecystokinin; neuromodulation; gustation; taste; neuropeptide
Stimulation of sensory receptors ultimately leads to perception by initiating transduction of incoming physicochemical energy into electrical events that are decipherable by the CNS. For gustation, perception is initiated by stimulation of primary receptor cells located in taste buds distributed throughout the oral cavity. Gustatory stimuli are thought to use specific transduction pathways that are, in most cases, initiated by specific receptors but use a wide variety of transduction mechanisms (Herness and Gilbertson, 1999; Gilbertson et al., 2000; Lindemann, 2001; Margolskee, 2002). Receptors for some tastants (e.g., sweet and bitter) are coupled to second messenger pathways, including the modification of cAMP and inositol trisphosphate levels, whereas others, such as salty, may interact directly with ion channels. Despite recent advances in the molecular biology of taste receptor cells (TRCs), such as the recent cloning of families of taste receptors (Hoon et al., 1999; Adler et al., 2000; Chandrashekar et al., 2000; Chaudhari et al., 2000; Matsunami et al., 2000; Montmayeur et al., 2001; Nelson et al., 2001, 2002), the mechanisms coupling activation of these receptors to variously expressed ion channels, such as sodium, potassium, calcium, and chloride channels, or intracellular calcium stores remain enigmatic. Multiple transduction cascades coexist within single cells, and the types of transduction cascades vary across cells.

An additional layer of complication arises when one considers routes for information transfer within the taste bud. Although

Received June 17, 2002; revised Sept. 3, 2002; accepted Sept. 9, 2002.

This work was supported by National Science Foundation Integrative Biology and Neuroscience Grant 9724062 and National Institutes of Health Grant DC00401.

Correspondence should be addressed to Dr. M. Scott Herness, College of Dentistry, The Ohio State University, 305 West 12th Avenue, Columbus, OH 43210. E-mail: herness.1@osu.edu.

Copyright (C) 2002 Society for Neuroscience $0270-6474 / 02 / 2210018-12 \$ 15.00 / 0$ traditional views considered communication by an unidentified neurotransmitter from the receptor cell to the afferent nerve, the search for this transmitter has revealed not only multiple transmitters within the taste bud but also multiple communication routes as well. To date, data have accumulated for serotonin (Kim and Roper, 1995; Herness and Chen, 1997; Ren et al., 1999), norepinephrine (NE) (Herness and Sun, 1999; Herness et al., 2002), glutamate (Chaudhari et al., 1996; Caicedo et al., 2000a,b), GABA (Obata et al., 1997), and acetylcholine (Ogura, 2002) within vertebrate taste buds. Evidence that taste receptor cells respond to neurotransmitters suggests cell-to-cell communication among cells within the bud to be viable processing avenues. Thus, these transmitters are thought to participate not only in traditional information transfer from the receptor cell to the afferent nerve but also among taste receptor cells. It is also possible that taste receptor cells could respond to other modulatory agents, such as neuropeptides. A recent publication suggests that TRCs are modulated by the peptide leptin via expression of leptin receptor (Kawai et al., 2000).

This communication reports another putatively important signaling molecule within the taste bud, cholecystokinin (CCK). CCK is a multifunctional peptide localized along the brain-gut axis. It occurs in enteroendocrine cells of the small intestine, as well as in peripheral and central neurons, and regulates multiple gastrointestinal (GI) functions, such as gastric motility and pancreatic enzyme secretion. As one of the most abundant neuropeptides in the brain, CCK is thought to influence membrane excitability via both neuromodulatory and neurotransmitter mechanisms. A well known role, connecting the brain-gut axis, is as a putative satiety factor. This study reports the novel observation that CCK is localized within subsets of taste receptor cells and that it alters physiological 
properties of subsets of taste receptor cells and consequently their electrical excitability.

\section{MATERIALS AND METHODS}

Anesthesia and tissue/cell preparation. Experiments were performed on adult male Sprague Dawley rats. All procedures were approved by the University's Laboratory Animal Care and Use Committee and adhered to the National Institutes of Health Guide for the Care and Use of Laboratory Animals. Animals were brought to a surgical level of anesthesia by intraperitoneal injection of $0.09 \mathrm{ml}$ of a ketamine (per $100 \mathrm{gm}$ of body weight) $(91 \mathrm{mg} / \mathrm{ml})$ (Fort Dodge Laboratories) acepromazine $(0.09 \mathrm{mg} / \mathrm{ml})$ (Butler Laboratories) mixture before kill and excision of foliate (FOL) and circumvallate (CV) papillae. For immunocytochemistry, excised papillae were immersion fixed. For physiological analysis, isolated taste receptor cells were dissociated from excised tissue by incubation in cysteine-activated $(1 \mathrm{mg} / \mathrm{ml})$ Papain $(14 \mathrm{U} / \mathrm{ml})$, divalentfree solution (in mM: $80 \mathrm{NaCl}, 5 \mathrm{KCl}, 26 \mathrm{NaHCO}_{3}, 2.5 \mathrm{NaH}_{2} \mathrm{PO}_{4} \cdot \mathrm{H}_{2} \mathrm{O}$, 20 D-glucose, and 1 EDTA) as described previously (Herness, 1989a; Herness and Sun, 1995). For PCR analysis, whole taste buds were isolated from posterior taste papillae by enzymatic dissociation using 2 $\mathrm{mg} / \mathrm{ml}$ elastase and $2 \mathrm{mg} / \mathrm{ml}$ dispase in mammalian physiological saline (in mM: $120 \mathrm{NaCl}, 20 \mathrm{KCl}, 10 \mathrm{HEPES}$, and 2 BAPTA, $\mathrm{pH}$ 7.4). Taste buds were harvested using a suction pipette and collected into a $1.5 \mathrm{ml}$ microtube containing $100 \mu \mathrm{l}$ of TRIzol reagent for reverse transcriptase (RT)-PCR experiments.

Immunocytochemistry. Excised foliate or circumvallate papillae were immersion fixed in Bouin's fixative (71\% saturated picric acid, 24\% glacial acetic acid, and $5 \%$ formalin) at $4^{\circ} \mathrm{C}$ for $4-24 \mathrm{hr}$. Tissue blocks were dehydrated, embedded in paraffin, and sectioned on a rotary microtome at $8 \mu \mathrm{m}$ thickness. Tissue sections were subsequently deparaffinized, rehydrated, and blocked with $0.5 \% \mathrm{H}_{2} \mathrm{O}_{2}$ in methanol, 5\% dry milk dissolved in $0.01 \mathrm{M}$ PBS, $\mathrm{pH} 7.4,0.75 \%$ gelatin dissolved in PBS, followed by a $1.5 \%$ solution of normal goat serum, each for $10 \mathrm{~min}$ at room temperature. Antiserum was applied to the sections, and the slides were housed in a closed moist chamber for $48-72 \mathrm{hr}$ at $4^{\circ} \mathrm{C}$. After rinsing in PBS, the secondary antibody, biotinylated goat anti-rabbit $\mathrm{IgG}$, was applied for $30 \mathrm{~min}$ at room temperature followed by a $15 \mathrm{~min}$ rinse in three changes of PBS. An avidin-biotin-horseradish peroxidase complex (Vectastain ABC Elite technique; Vector Laboratories, Burlingame, CA) was applied for $60 \mathrm{~min}$ at room temperature, rinsed, and developed by reaction in $0.05 \%$ 3,3'-diaminobenzidine tetrahydrochloride (DAB; Sigma, St. Louis, MO) with $0.012 \% \mathrm{H}_{2} \mathrm{O}_{2}$ in 0.05 m Tris buffer, $\mathrm{pH}$ 7.6. Primary polyclonal antisera to CCK were commercially purchased from Cambridge Research Biochemicals (Valley Stream, NY), Serotec (Raleigh, NC), and Chemicon (Temecula, CA) and used at dilutions ranging from 1:500 to 1:5000. Methods and antibody specificity were assessed by elimination of the primary antibody, dilution series of the primary antibody, preabsorption controls with the primary antibody, and inclusion of positive control tissue. Substitution of the primary antibody by normal goat serum or PBS and subsequent processing with secondary goat anti-rabbit followed by avidin-biotin DAB development yielded no observed positive immunoreactivity. In addition, positive immunoreactivity depended on dilution of the primary antibody; positive immunoreactivity was eliminated at a sufficiently dilute $(1: 10,000)$ primary antibody concentration. Thus, immunoreactive product was not the result of nonspecific secondary antibody binding or binding of the tertiary complex to endogenous biotin. Antibody specificity was tested with preabsorption controls. Synthetic CCK-8 (Cambridge Research Biochemicals) at 1 and $10 \mathrm{~nm} / \mathrm{ml}$ concentrations was incubated with 1:1000 primary antibody dilution at $4{ }^{\circ} \mathrm{C}$ for $24 \mathrm{hr}$ before its application to tissue sections, which were subsequently processed with the standard technique. Both concentrations of synthetic antigen eliminated positive immunoreactivity. Positive control tissue known to contain cholecystokinin antigen, duodenal tissue and cerebral cortex, was also included in experiments with each antibody and produced the expected results.

$R T$-PCR and RT-nested PCR. RT-PCR and RT-nested PCR experiments were performed on total RNA isolated from individually collected taste buds. Whole taste buds (100 taste buds) harvested from circumvallate papillae were collected into a $1.5 \mathrm{ml}$ microtube containing $100 \mu \mathrm{l}$ of TRIzol reagent (Invitrogen, Carlsbad, CA). Total RNA was also isolated from tissues, such as adult rat brain, heart, lung, adipose tissue, liver, and kidney, which served as positive and negative controls, using a Totally RNA isolation kit (Ambion, Austin, TX) according to the manufacturer's instructions. RNA was treated with DNase-I (Amplification Grade; Invitrogen). Total RNA (250 ng) extracted from pure taste buds or from control tissues was used to synthesize the first-strand cDNA. RNA was incubated at $70^{\circ} \mathrm{C}$ for $10 \mathrm{~min}$ with $500 \mathrm{ng}$ of oligo(dT) $)_{12-18}$ primer. Subsequently, the following components were added to the reaction, with a final total volume of $20 \mu \mathrm{l}$ : $1 \times$ first-strand buffer, $10 \mathrm{mM}$ DTT, $500 \mu \mathrm{M}$ each deoxyNTP (dNTP), and 200 U of SuperScript II RNase H-reverse transcriptase (Invitrogen).

PCR analysis was begun using the following sets of primers published previously: forward primer 5'-CAA GAT CTA TGA AGT GCG GCG TGT-3', reverse primer 5'-GGC GGA TCC ACT ACG ATG GGT A-3' (Shimizu et al., 1998), forward primer 5'-AGC CGG TAG TCC CTG TAG AA-3', and reverse primer 5'-GTG CGT GGT TGT TTT CTC AT-3' (Miyasaka et al., 1997). Additional primer sets, for use with the nested PCR protocol, were designed from the published GenBank sequences using Primer Express 1.0 (Applied Biosystems, Foster City, CA). These primer sequences are as follows: outer forward primer, 5'-TGC CCT CAA CTT AGC TGG ACA-3'; outer reverse primer, 5'-TGT TTT CTC ATT CCG CCT CCT-3'; inner forward primer, 5'-ACT GCT AGC CCG ATA CAT CCA-3'; and inner reverse primer, 5'-ATC CAT CCA GCC CAT GTA GTC-3'. PCR was performed in a volume of $50 \mu \mathrm{l}$ using $1 \mu \mathrm{l}$ of cDNAs for each reaction. The standard reaction mixture consisted of $1 \times$ PCR buffer (200 mM Tris- $\mathrm{HCl}, \mathrm{pH} 8.4$, and $500 \mathrm{mM} \mathrm{KCl}$ ), $0.2 \mu \mathrm{M}$ forward and reverse primer, $0.2 \mathrm{~mm}$ each $\mathrm{dNTP}, 1.5 \mathrm{mM} \mathrm{MgCl}_{2}$, and $2.5 \mathrm{U}$ of platinum Taq DNA polymerase (Invitrogen). The PCR profile was $94^{\circ} \mathrm{C}$ at 5 min (one cycle), $94^{\circ} \mathrm{C}$ at $30 \mathrm{sec}, 55^{\circ} \mathrm{C}$ at $30 \mathrm{sec}, 72^{\circ} \mathrm{C}$ at $45 \mathrm{sec}(35 \mathrm{cycles})$, and $72^{\circ} \mathrm{C}$ at $10 \mathrm{~min}$ (one cycle). This same profile (except cycle number) was used for nested PCR. For the first PCR, $1 \mu \mathrm{l}$ of cDNA was amplified by using outer primers $(0.2 \mu \mathrm{M}$ each $)$ in the standard $50 \mu \mathrm{l}$ PCR mixture with 35 cycles. For the second PCR, $1 \mu \mathrm{l}$ of first undiluted PCR product was amplified using inner primers $(0.2 \mu \mathrm{M}$ each) in the standard $50 \mu \mathrm{l} \mathrm{PCR}$ mixture with 40 cycles. Additionally, a one-tube RT-PCR strategy with gene-specific primers using a SuperScript One-Step RT-PCR with platinum Taq kit (Invitrogen) according to the manufacturer's instructions was also used as a different approach to confirm our results. A total of $0.1-0.5 \mu \mathrm{g}$ of total RNA isolated from pure taste buds or control tissues was used.

Controls for DNA contamination and PCR carryover were performed. These included RT - (RT-free) to control for genomic contamination and no template control. Positive and negative control tissues were routinely run in parallel with experimental reactions. Primers for housekeeping genes [ glyceraldehyde-3-phosphate dehydrogenase (GAPDH)] and robustly expressed taste-specific genes [gustducin (GUST)] were performed.

PCR products were analyzed by $1.5 \%$ agarose gel electrophoresis, stained with ethidium bromide $(0.5 \mu \mathrm{g} / \mathrm{ml})$, and visualized by UV illumination. The identity of the band of interest (PCR product of expected size) was confirmed by sequencing. PCR products were purified using the Concert Rapid PCR Purification System (Invitrogen). Purified samples and primers were submitted to the Plant-Microbe Genomic Facility at The Ohio State University facility for sequencing.

Electrophysiology. All experiments were performed on isolated taste receptor cells dissociated from circumvallate and foliate papillae of the rat tongue using standard patch-clamp procedures in the whole-cell or perforated patch recording modes as described previously (Herness, 2002). Microelectrode pipettes were pulled on a gas-cooled multistage puller from $1.5 \mathrm{~mm}$ (outer diameter) borosilicate glass (World Precision Instruments, Sarasota, FL). The standard extracellular fluid (ECF) solution included (in mM): $126 \mathrm{NaCl}, 1.25 \mathrm{NaH}_{2} \mathrm{PO}_{4} \cdot \mathrm{H}_{2} \mathrm{O}, 5 \mathrm{KCl}, 5 \mathrm{Na}$ HEPES, $2 \mathrm{MgCl}_{2}, 2 \mathrm{CaCl}_{2}$, and 10 glucose; $\mathrm{pH}$ was adjusted to 7.4 with $\mathrm{NaOH}$. The composition of pseudo-intracellular fluid (ICF) used for filling the recording pipette consisted of (in $\mathrm{mM}$ ): $140 \mathrm{KCl}, 2 \mathrm{MgCl}_{2}, 1$ $\mathrm{CaCl}_{2}, 11$ EGTA, $10 \mathrm{HEPES}$, and 4 ATP (disodium salt). Most experiments were performed using the perforated patch configuration with amphotericin B as the ionophore $(400 \mu \mathrm{g} / \mathrm{ml}$ in the ICF). The composition of the perforated patch ICF was (in mM): $55 \mathrm{KCl}, 75 \mathrm{~K}_{2} \mathrm{SO}_{4}, 8$ $\mathrm{MgCl}_{2}$, and 10 HEPES. Resistances were typically 5-7 $\mathrm{M} \Omega$ when filled with ICF and measured in ECF. The composition of ICF for recording inwardly rectifying potassium current $\left(\mathrm{K}_{\mathrm{IR}}\right)$ in conventional whole-cell configuration recording mode consisted of (in mM): $140 \mathrm{KCl}, 2 \mathrm{MgCl}_{2}, 1$ $\mathrm{CaCl}_{2}, 11$ EGTA, 10 HEPES, and 4 ATP (magnesium salt). The extracellular solution for recording $\mathrm{K}_{\mathrm{IR}}$ consisted of the standard ECF recipe with the replacement of $95 \mathrm{~mm} \mathrm{NaCl}$ by an equivalent amount of $\mathrm{KCl}$ (final extracellular potassium concentration of $100 \mathrm{mM}$ ).

The pipette tip was positioned to contact the cell membrane, and negative pressure was applied to its interior to facilitate gigaseal formation. Junction potentials were corrected before the electrode contacted the cell. Seal resistances were on the order of several decades of giga- 
ohms. Additional negative pressure was applied to enter whole-cell recording mode. For perforated patch recordings, $\sim 30 \mathrm{~min}$ were required to reach a stable level of recording after gigaseal formation. Fast and slow capacitance compensation was used as necessary with amplifier controls. Cell membrane capacitance and uncompensated series resistance were adjusted to produce optimal transient balancing. Membrane capacitance was 3-6 pF; series resistance averaged $10 \mathrm{M} \Omega$ in conventional whole-cell mode and 20-50 M $\Omega$ in most amphotericin B-perforated patch-clamp recordings. Low-pass filtering caused by resistancecapacitance coupling was considered minimal. The product of these factors produces a time constant of $30-300 \mu \mathrm{sec}$ or a cutoff frequency $(1 / 2 \pi \mathrm{RC})$ of $1.6-16.6 \mathrm{kHz}$.

CCK was focally applied through a pipette positioned $\sim 500 \mu \mathrm{m}$ from the recorded cell. Pharmacological agents were added directly to ECF solution. Cholecystokinin receptor antagonists were obtained from Sigma-RBI (Natick, MA) and ML Laboratories (Liverpool, UK). CCK was obtained from Bachem (King of Prussia, PA). All physiological experiments (patch clamping and calcium imaging) were performed with the sulfated octapeptide form of CCK (CCK-8S). CCK was dissolved in $0.9 \% \mathrm{NaCl}$ with $0.5 \% \mathrm{NaHCO}_{3}$, aliquoted, and stored at $-20^{\circ} \mathrm{C}$. Data were acquired with a high-impedance amplifier (Axopatch 1-B; Axon Instruments, Union City, CA), a Pentium-based $450 \mathrm{MHz}$ computer, a 12 bit, $330 \mathrm{kHz}$ analog-to-digital converter (Digidata 1200; Axon Instruments), and a commercial software program (pClamp, versions 7.0 or 8.01; Axon Instruments). Membrane currents were acquired after lowpass filtering with a cutoff frequency of $5 \mathrm{kHz}($ at $-3 \mathrm{~dB}$ ). A softwaredriven, digital-to-analog converter generated the voltage protocols. A $\mathrm{P} / 4$ leak subtraction protocol was used. Recordings were made at room temperature. Data are presented as mean \pm SE. Student's $t$ test was used to evaluate the statistical significance of the difference between means. Values of $p<0.05$ were considered to indicate statistical significance.

Calcium imaging. Intracellular calcium levels in dissociated taste receptor cells were monitored using standard ratiometric techniques with the calcium-sensitive dye fura-2 (Molecular Probes, Eugene, OR) and a commercially available software package for data acquisition and analysis (SimplePCI; Compix, Cranberry Township, PA). These methods were described recently (Herness, 2002). Briefly, taste receptor cells were plated into the experimental chamber lined with a poly-lysine-coated coverslip, loaded with fura-2 AM ester (5 $\mu \mathrm{M}$ fura-2, $0.05 \%$ Pluronic $\mathrm{F}-127$, and $1 \% \mathrm{BSA}$ ) for $60 \mathrm{~min}$, and then rinsed. Images were acquired with a CCD camera (Hamamatsu Orka; Hamamatsu Photonic KK, Hamamatsu City, Japan) through an oil immersion $40 \times$ objective lens on an inverted microscope. For dual-wavelength ratiometric calcium measurements, pairs of fluorescent images were recorded at 340 or $380 \mathrm{~nm}$ excitation. Excitation wavelengths were produced with a software-driven monochromator (Polychrome II, Photonics; Applied Scientific Instrumentation, Eugene, OR), and light was collected through a $510 \mathrm{~nm}$ emission filter. Paired images were obtained once every $10 \mathrm{sec}$ during the stimulation period and once per minute during baseline measurements to minimize bleaching. Stimuli were applied by focal application with a quartz pipette positioned $\sim 100 \mu \mathrm{m}$ from the cell against a background perfusion of ECF. Ratios (340:380) before, during, and after stimulus presentation were taken to reflect changes of intracellular $\mathrm{Ca}^{2+}$ in response to the stimulus. Exposure levels at 340 and $380 \mathrm{~nm}$ excitation wavelengths were chosen to produce images well below saturated levels and to optimize ratios. Ratios were calculated from the mean intensity of pixels within a software-defined region of interest within the cell. Corrected ratios were background subtracted, which helped to control for endogenous fluorescence of some stimuli, such as quinine.

\section{RESULTS}

\section{Distribution of CCK-like immunoreactivity in taste receptor cells of the oral cavity}

Taste receptor cells displaying reaction product for CCK-like immunoreactivity were observed in taste buds of foliate and circumvallate papillae, palate, and the nasoincisor ducts (NIDs) using three commercially available primary antibodies to the sulfated octapeptide form of cholecystokinin. No obvious differences in the staining pattern were evident among these antibodies. Positive cells displayed a characteristic distribution of reaction product; reaction product was confined to the cytosol, whereas nuclei appeared as clear circles (Fig. 1). There was no
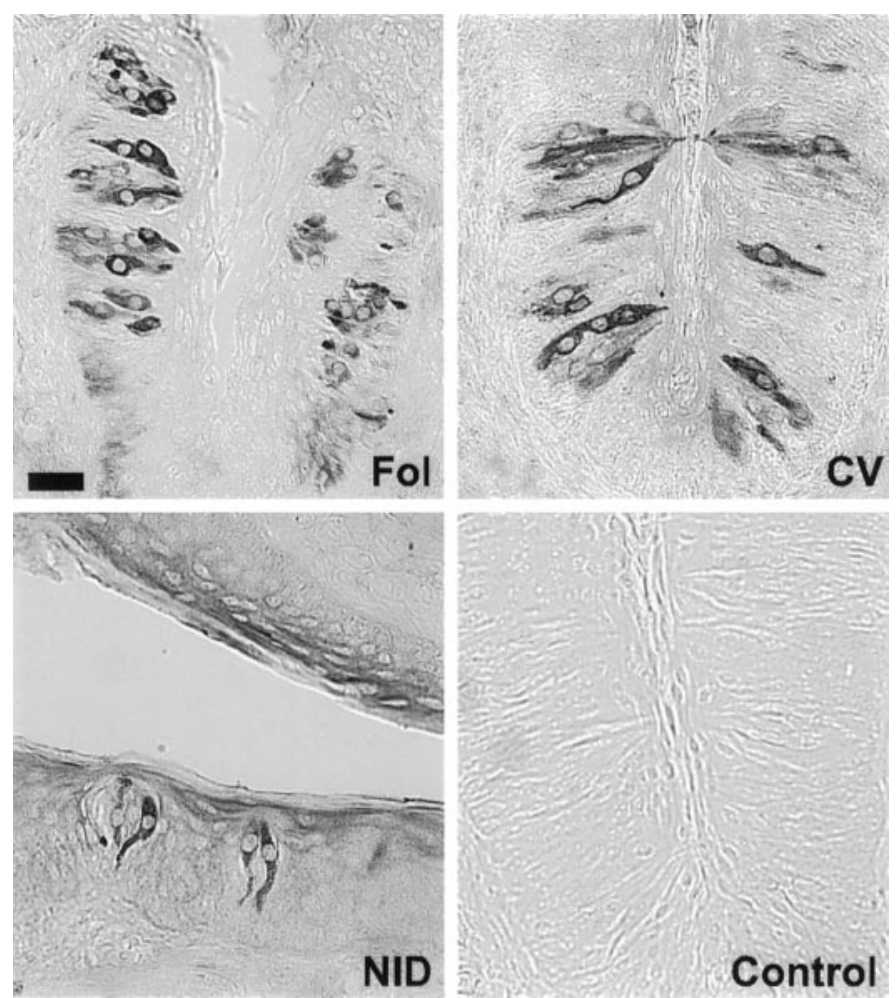

Figure 1. Examples of taste receptor cells from varying lingual structures displaying CCK-like immunoreactivity. Dark cytoplasmically distributed reaction product is seen in subsets of taste receptor cells within taste buds of the gustatory epithelium. Immunopositive taste receptor cells typically display large, round nuclei, devoid of reaction product and long processes, characteristics typical of light taste receptor cells. Fol, Foliate papillae. The control panel is a section with omission of the primary antibody. Scale bar, $20 \mu \mathrm{m}$.

evidence of polar distribution; reaction product extended evenly throughout the cytoplasm from the apical to basal end of the cell. There was no obvious difference in the distribution of positive cells among any observed taste buds. In foliate and circumvallate papillae, both dorsal and ventrally located taste buds appeared equally likely to contain positive cells. Similarly, no obvious difference was noted in the location of positive cells within a taste bud. Positive cells were observed within the center or periphery of the bud. Moreover, immunoreactive cells were sometimes observed to border one another. Thus, in these taste budcontaining structures, a similar pattern of CCK-like immunoreactivity was observed in most taste buds. In contrast, taste buds from fungiform papillae displayed inconsistent results. Fungiform papillae, which contain a single taste bud in the rat, were often high in nonspecific background, and unambiguously labeled cells in fungiform taste buds were difficult to distinguish from surrounding nonspecific reaction product.

The number of labeled cells per taste bud was estimated by counting the number of labeled cells in sectioned taste buds in every fourth tissue section (at $8 \mu \mathrm{m}$ each) to prevent double counting of cells. In a total of 1564 sectioned taste buds from 12 separate experiments, there were 3750 labeled cells. This produced an average of 2.4 labeled cells per cross-sectioned taste bud. Because a single taste bud ( $\sim 50 \mu \mathrm{m}$ in diameter) encompasses approximately six sections, and because we assume that different cross-sectional areas of sectioned taste buds were equally represented in our analysis, we estimate that an individual taste 
bud might contain $\leq 14$ CCK-expressing taste receptor cells. This estimate may be a high approximation, because taste buds with large cross-sectional areas were easier to count than smaller cross sections and hence likely to be represented more often than marginal cross sections. A careful serial reconstruction would be required for a more accurate assessment of the number of CCKlabeled cells per taste bud.

Representative photomicrographs of positive immunoreactive taste receptor cells from FOL and CV papillae and NIDs are illustrated in Figure 1. Immunoreactive cells typically have round regularly shaped nuclei. This feature is typical of light rather than dark cells (Pumplin et al., 1997). Classification into light and dark categories is a common anatomical descriptor of subclasses of taste receptor cells based on their electro-opacity under the electron microscope. Positive control tissue (data not shown) included the duodenum and cortex. Many positive "I" cells were noted in and around the duodenal glands located within the lamina propria beneath the villi. Numerous immunopositive neurons were observed in rat cortex, where CCK-expressing cells are abundant in layers II and III. Omission of the primary antibody (Fig. 1, control) or secondary antibody eliminated all staining. Similarly, preabsorption control with 1:1000 primary antibody dilution and either 1 or $10 \mathrm{ng} / \mathrm{ml}$ synthetic octapeptide eliminated all staining.

\section{Localization of CCK mRNA to taste buds by RT-PCR}

To confirm the immunocytochemical results, experiments were conducted using RT-PCR to verify the expression of cholecystokinin mRNA in taste receptor cells. RT-PCR was performed on RNA isolated from individually collected taste buds as starting material. Taste buds from circumvallate and foliate papillae were enzymatically dissociated, and 100 buds were harvested under a dissecting microscope using a micropipette and micromanipulator. Single buds were pooled, cells were lysed, and total RNA was extracted. Initial attempts at RT-PCR on mRNA extracted from populations of pure taste buds using CCK-specific primers were unable to produce detectable PCR product, although GUST and GAPDH primers produced strong bands, and these same CCK primers performed well on control tissue (cerebral cortex and duodenum). Therefore, the possibility that CCK mRNA is expressed in low abundance in TRCs and hence not easily detectable by PCR protocols was considered. This possibility was tested using RT-PCR experiments with a nested PCR protocol.

Nested primers were designed with separate pairs of outer and inner primers that yielded PCR products of 462 or $127 \mathrm{bp}$, respectively. Outer and inner primer sets were optimized on cDNA transcribed from RNA isolated from the cerebral cortex as a positive control tissue (Fig. 2, bottom, CCK-CNS outer, CCKCNS inner). Negative controls include CCK inner primers on template derived from lung RNA and no template $\left(\mathrm{H}_{2} \mathrm{O}\right)$ controls. All experiments were performed with parallel negative control experiments that either omitted the reverse transcriptase enzyme $(\mathrm{RT}-)$ or template (water control). All control experiments yielded the expected results.

Using template DNA derived from taste buds, first-round amplification produced no detectable PCR when run on agarose gel (data not shown). However, when the reaction mixture was reamplified with internal primers, a strong band of correct size was evident (Fig. 2, top, CCK-TB inner). This product was sequenced to confirm its identity. These data verify that taste receptor cells express CCK mRNA, although apparently at very low levels.

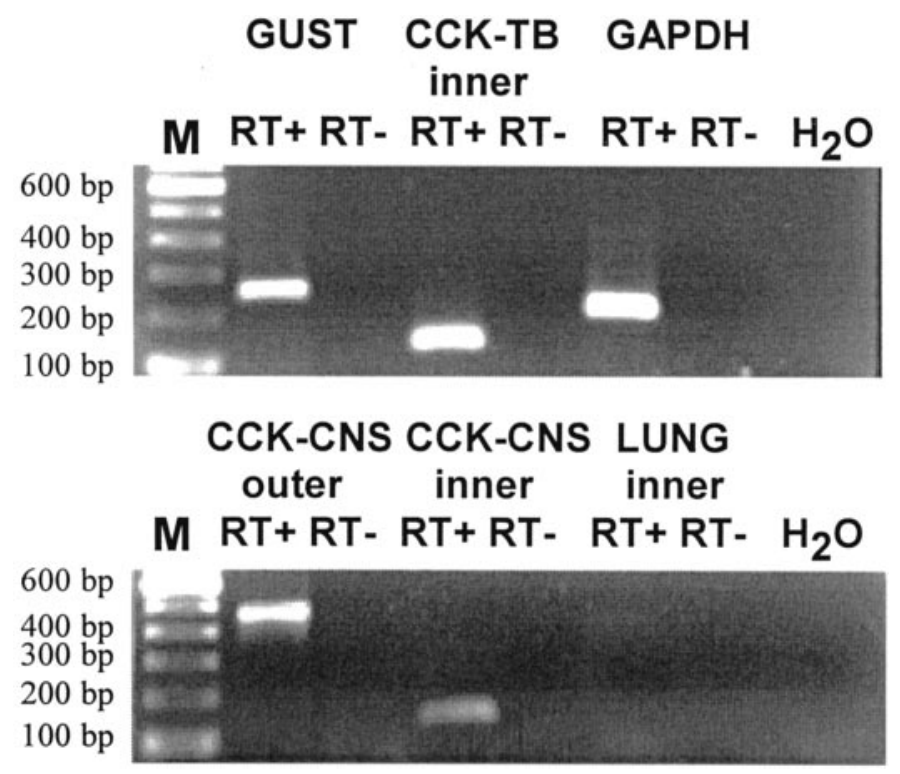

Figure 2. RT-PCR using nested primers demonstrates the presence of CCK mRNA in taste buds. First-round PCR using outer primers against CCK mRNA produced a fragment of the expected size (462 bp) in CNS (CCK-CNS outer) but not in taste bud or lung (data not shown). Using undiluted PCR product from first-round amplification and inner primers against CCK mRNA, a PCR product of the expected size (127 bp) was evident for both CNS (CCK-CNS inner) and taste buds (CCK-TB inner) but not against the negative control tissue lung (illustrated). PCR product was never observed in reactions that omitted either reverse transcriptase $(R T-)$ or starting material $\left(\mathrm{H}_{2} \mathrm{O}\right)$. PCR products of expected size were observed for the positive controls GUST and GAPDH. $M, 100$ bp size markers; $R T+$, RNA with SuperScript II; $R T-$, RNA without SuperScript II; $\mathrm{H}_{2} \mathrm{O}$, template-free control.

\section{Inhibition of outward potassium currents by application of exogenous CCK}

To begin examination of potential physiological actions of cholecystokinin within the taste bud, patch-clamp recordings, using the perforated patch technique, were performed on isolated taste receptor cells dissociated from rat circumvallate and foliate papillae. Focal application of exogenous cholecystokinin resulted in significant inhibition of outward potassium currents (Fig. 3A-C) without discernible effects on inward sodium currents. Figure $3 A$ illustrates a family of inward and outward currents recorded from a representative taste receptor cell before (ECF) and during application of $1 \mu \mathrm{M}$ CCK. Inhibition of the outward potassium current is evident without obvious effect on the transient sodium current that occurs at the beginning of the command step potentials. A plot of the current-voltage relationship (data not shown) demonstrated that the inhibition was effective at all suprathreshold potentials and that cholecystokinin application did not affect the activation threshold of the outward currents. Data from a different taste receptor cell, using a ramp protocol, are illustrated in Figure $3 B$. The ramp protocol, which more quickly $(166 \mathrm{mV} /$ sec) clamps the membrane potential through a range of voltage $(-100$ to $+100 \mathrm{mV})$, yielded similar results. Outward potassium currents, most evident at positive membrane potentials, were inhibited by application of $100 \mathrm{~nm}$ CCK. Using either method, outward potassium current was inhibited by $20-30 \%$, an amount typical of other effective stimuli on taste receptor cells, such as caffeine (Zhao et al., 2002), serotonin (Herness and Chen, 1997, 2000), or norepinephrine (Herness and Sun, 1999; Herness et al., 
Figure 3. Application of exogenous CCK inhibits outward potassium currents in dissociated taste receptor cells. $A$, Membrane currents evoked by step command potentials illustrated before and during application of $1 \mu \mathrm{M}$ CCK to the bath. Outward currents were diminished in the presence of CCK, whereas inward sodium currents were unaffected. $B$, Currents evoked by a ramp protocol demonstrate that outward components are inhibited by 100 nм CCK without noticeable effect on the activation potential. Inhibition is most evident at the more depolarized command potentials. $C$, Concentration dependence of the CCK-mediated inhibition of potassium current is illustrated. Responses were normalized to prestimulus current magnitudes. The solid triangle at the far left illustrates the response magnitude to all tested concentrations of CCK for nonresponsive cells $(103 \pm 1 \%)$. $D$, The percentage of tested cells that responded to CCK with an inhibition of potassium current increased as a function of peptide concentration. At the highest tested concentration $\left(10^{-5} \mathrm{M}\right)$, $50 \%$ of the 28 tested cells responded to CCK application. The number of cells contributing to each point is indicated in parentheses.
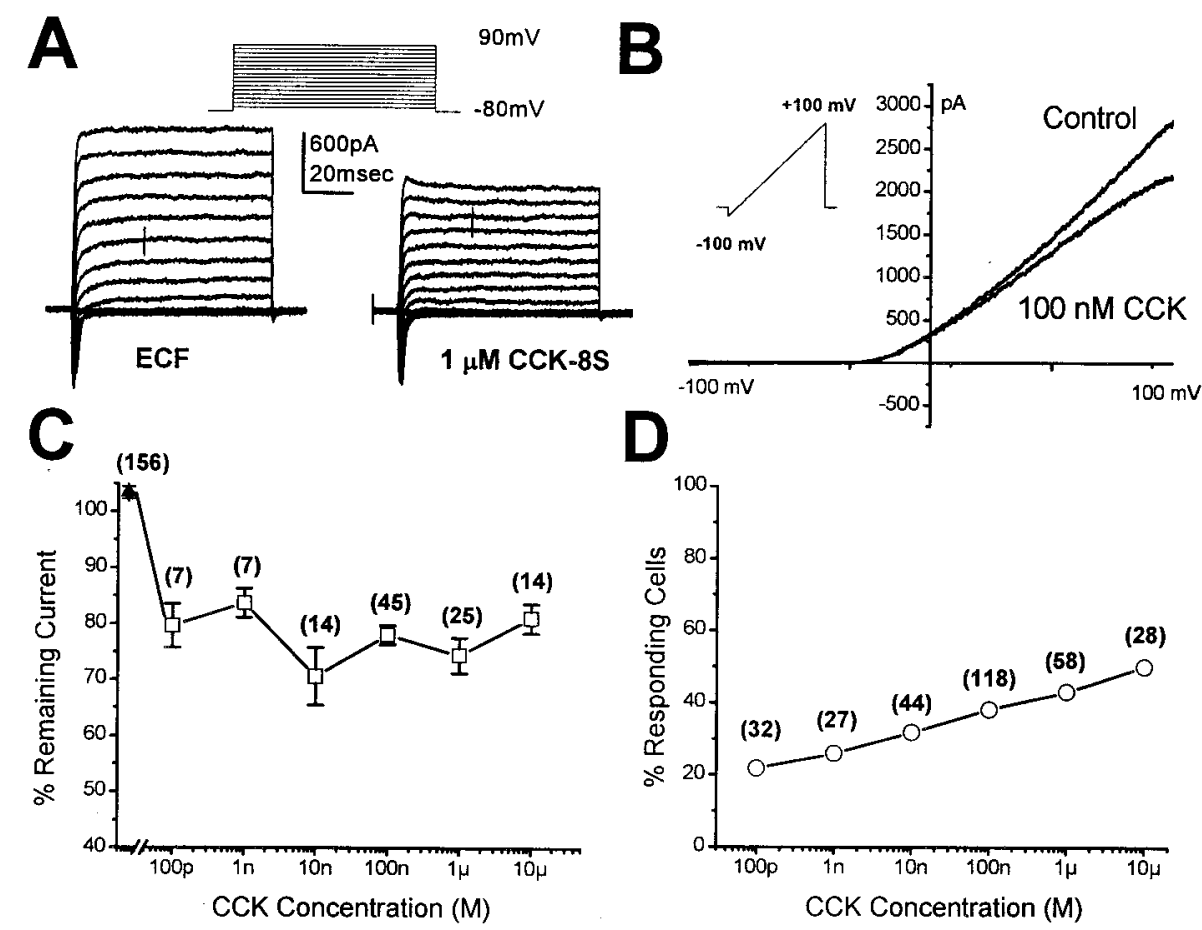

2002). Typically, inhibition was quick in onset with application of CCK to the bath and reversible with washout.

Six concentrations of CCK were tested, ranging from $100 \mathrm{pm}$ to $10 \mu \mathrm{M}$ (Fig. 3C). Data from step and ramp protocols were combined to determine concentration dependence. The percentage of remaining current was determined by calculating the current magnitude during CCK exposure to a test command potential of $+90 \mathrm{mV}$ divided by the current magnitude to the same command potential before CCK exposure. The concentration dependence of the inhibition of outward current to CCK was sharp; the lowest tested concentration of $100 \mathrm{pM}$ produced $80 \pm 4 \%$. The reference value (Fig. $3 C$, solid triangle) was determined as the percentage of remaining current value (as just described) of nonresponsive CCK cells to all test concentrations. The value of nonresponsive cells to CCK administration was $103 \pm 1 \%$. The number of cells contributing to each point is listed in parentheses. Taste receptor cells displayed sensitivity to CCK that favorably compares with the sensitivity of other cell types, such as the pancreatic acinar cell, which responds in the picomolar range (Williams, 2001).

Although not all tested cells were sensitive to CCK application, the number of responsive cells increased with increasing CCK concentration (Fig. 3D). The number of responding cells ranged from 25 to $45 \%$ of tested cells when exposed to CCK concentrations ranging from $0.1 \mathrm{~nm}$ to $10 \mu \mathrm{M}$. The total number of tested cells for each point is presented in parentheses. CCK-A receptors are known to exist in two affinity states, referred to as high and low affinity (cf. Williams and Blevins, 1993). It is possible that higher concentrations of CCK recruit receptors in the low-affinity state and thus increase the number of responsive cells. Another possibility is that higher concentrations of CCK may interact with other classes of chemoreceptors with appropriate side band sensitivity.

To gain insight into the type of receptor mediating the inhibition of potassium currents, pharmacology was used. The purpose of these experiments was twofold. First, because taste receptor cells are specialized chemoreceptors designed to respond to chemicals in their immediate environment, it is essential to demonstrate that the CCK-induced inhibition of potassium current is mediated by CCK receptors rather than another subclass of chemoreceptors [e.g., some peptides are reported to taste bitter, and hence, peptide stimulation could be mediated by bitter receptors, such as the T2 receptor (T2R) family]. Second, selective pharmacological analysis with cholecystokinin antagonists can preliminarily classify events mediated by CCK-A or CCK-B receptors. Three cholecystokinin receptor antagonists were used: (1) proglumide, a receptor antagonist effective for both CCK-A and CCK-B receptors; (2) lorglumide, an antagonist selective for CCK-A over CCK-B receptors; and (3) $3 S(-)\left[N^{\prime}-2,3\right.$-dehydro-1methyl-2-oxo5-phenyl-1H-1,4-benzodiazepin-3-yl]-1H-indole-2carboxamide (L-365,260), an antagonist with selectivity for CCK-B receptors over CCK-A receptors. Both $100 \mu \mathrm{M}$ proglumide or $100 \mu \mathrm{M}$ lorglumide were effective in preventing the inhibition of potassium current produced by CCK application. Figure $4 A$ illustrates a sample response of a taste receptor cell to $100 \mathrm{~nm}$ CCK during and after proglumide exposure. The potassium current was measured as the magnitude in response to a test pulse from the holding potential of $-80 \mathrm{mV}$ to $+90 \mathrm{mV}$ and is plotted against time during the recording session. CCK produced no inhibition of the potassium current when presented with proglumide but was effective in inhibiting the current after proglumide was rinsed from the bathing solution. A similar sample response using lorglumide is presented in Figure $4 B$. The increase in current magnitude at the start of the recording session is a result of the settling period of the series resistance, which is typical in perforated patch recording. Note that no inhibition of the potassium current is evident during lorglumide exposure, whereas after lorglumide was rinsed from the bathing medium, CCK produced a clear and reversible inhibition of the potassium current. Summarized data are presented in Figure 4D. Application of CCK resulted in an inhibition of potassium current that was $78 \pm 2 \%$ of its original magnitude. CCK in the presence of proglumide reduced the current to only $99 \pm 2 \%$ of its original 


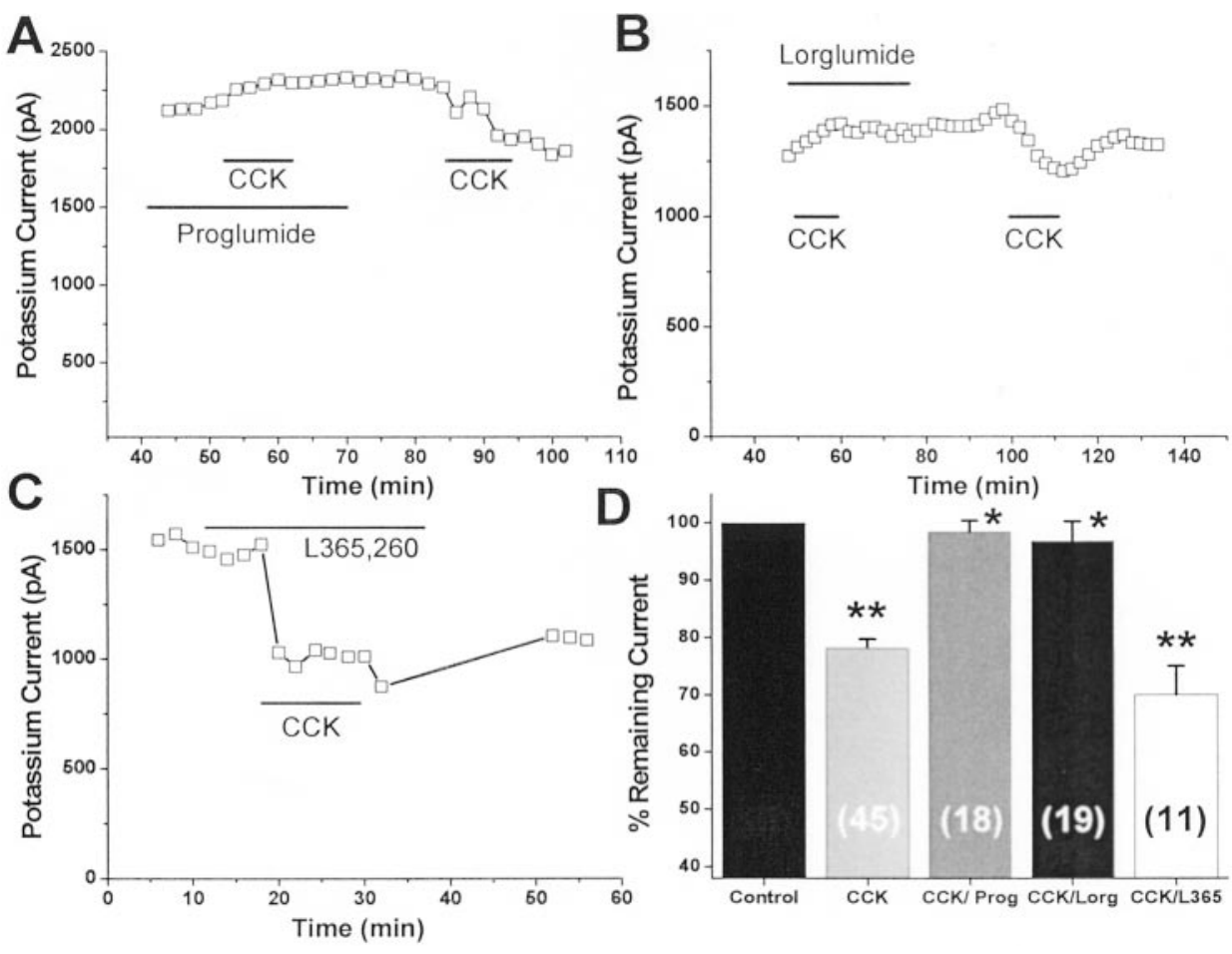

pared with the control group. The number of cells contributing to each point is indicated in parentheses.
Figure 4. Inhibition of outward potassium current is mediated by CCK-A but not CCK-B receptors. Three CCK receptor antagonists were tested: proglumide, a nonspecific CCK receptor antagonist; lorglumide, a CCK-A receptor-selective antagonist; and L-365,260, a CCK-B receptor-selective antagonist. $A$, Potassium current magnitude, plotted over time, is unaltered by CCK in the presence of 100 $\mu \mathrm{M}$ proglumide but inhibits the current after washout. $B, \mathrm{CCK}$ is ineffective in the presence of $100 \mu \mathrm{M}$ lorglumide but inhibits the potassium current after its washout. $C, \mathrm{CCK}$ is highly effective in inhibiting potassium current in the presence of the CCK-B receptor antagonist L-365,260 (100 $\mu \mathrm{M})$. $D$, Summary data for the three CCK receptor antagonists. CCK alone reduced current to $78 \pm 1.6 \%$ of its initial value, whereas it was ineffective in the presence of either proglumide (Prog) or lorglumide (Lorg) $(99 \pm 2$ or $97 \pm 3.5 \%$, respectively). L-365,260 ( $L 365$ ) was without effect on the CCK-mediated inhibition $(70 \pm$ $5 \%$ ). Student's $t$ test comparison of the indicated groups revealed significant differences of the means $(p<0.01)$. Single asterisks indicate statistical significance $(p<0.01)$ when proglumide or lorglumide groups were compared with the CCK group. Double asterisks indicate statistical significance $(p<0.01)$ when CCK or L-365,260 groups were com- magnitude. Similarly, CCK in the presence of lorglumide reduced the current to $97 \pm 3 \%$. Thus, CCK was essentially ineffective in the presence of these CCK receptor antagonists. Both the proglumide and the lorglumide group were significantly different when compared with the CCK group $\left({ }^{*} p<0.01\right)$. However, L-365,260 was without effect on CCK application. A sample response produced by $100 \mathrm{nM}$ CCK in the presence of $100 \mathrm{~nm}$ L-365,260 is presented in Figure 4C. A clear inhibition of the potassium current magnitude that coincides with the application of CCK is evident. Summarized data are presented in Figure 4D. The application of CCK in the presence of L-365,260 reduced the current magnitude to $70 \pm 5 \%$ of its original magnitude, comparable with that produced by CCK alone and significantly different from control values $(* * p<0.01)$.

CCK-A receptors are typically coupled to the inositol trisphosphate/diacylglycerol (DAG) second messenger system and hence could involve PKC-mediated phosphorylation events (Williams, 2001). Experiments were performed to determine whether CCKmediated inhibition of potassium current was dependent on PKC phosphorylation using two kinase inhibitors, bisindolylmaleimide (BIS), with high affinity for PKC, and H89, with high affinity for the cAMP-dependent kinase PKA. Potassium current was evoked by a test pulse from $-80 \mathrm{mV}$ to $+90 \mathrm{mV}$, and inhibition of this current was measured under three conditions: (1) $100 \mathrm{nM}$ CCK, (2) $100 \mathrm{~nm} \mathrm{CCK}$ in the presence of $100 \mathrm{~nm}$ bisindolylmaleimide, or (3) $100 \mathrm{~nm} \mathrm{CCK}$ in the presence of $50 \mathrm{~nm} \mathrm{H89}$ (Fig. $5 A$ ). Typically, the kinase inhibitor was presented for 8-10 min before administration of CCK. CCK reduced the current to $78 \pm$ $2 \%$ of its original value, whereas CCK in the presence of bisindolylmaleimide was similar to control values $(96 \pm 3 \%)$. The difference in the means of these groups was statistically significant $(p<0.001)$. In contrast, CCK in the presence of H89 was similar to CCK alone $(72 \pm 5 \%)$. The mean of the CCK/H89 group was significantly different from the CCK/BIS group $(p<0.001)$ but
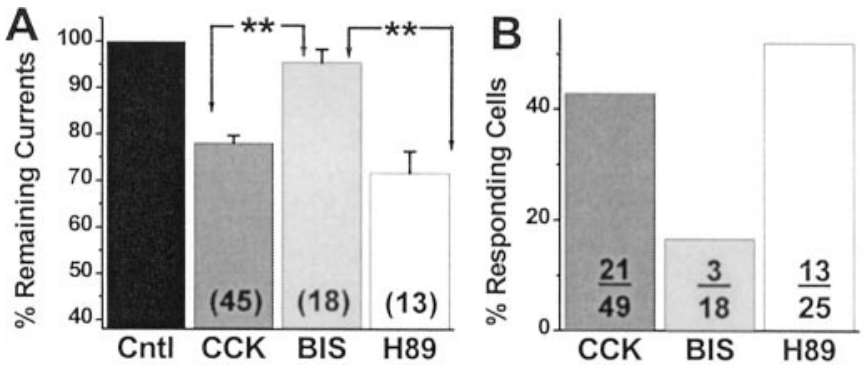

Figure 5. Inhibition of potassium current by CCK is dependent on PKC but not PKA phosphorylation. $A$, The magnitude of outward current in ECF (control); $100 \mathrm{nM}$ CCK and $100 \mathrm{~nm}$ bisindolylmaleimide, a PKCspecific inhibitor (BIS); or $100 \mathrm{~nm} \mathrm{CCK}$ and $50 \mathrm{~nm} \mathrm{H89} \mathrm{(H89)} \mathrm{is} \mathrm{presented.}$ H89 had no effect on CCK-mediated inhibition, whereas CCK was ineffective in the presence of bisindolylmaleimide $(95.5 \pm 2.8 \%)$. Statistical comparison of the groups indicated by the arrows was significant $(* * p<$ 0.001). The number of cells contributing to each point is indicated. $B$, The number of cells responding to CCK in the presence of the PKA inhibitor $\mathrm{H} 89$ (13 of 25) is comparable with that responding to CCK alone (21 of 49), whereas CCK is almost ineffective as an inhibitor of potassium currents in the presence of the PKC inhibitor bisindolylmaleimide ( 3 of 18).

not significantly different from the CCK alone group $(p=0.12)$. These data suggest that CCK-mediated inhibition of potassium current involves PKC phosphorylation but does not involve PKA phosphorylation events. This notion is similarly reflected when the percentage of tested cells responding to $\mathrm{CCK}$ or $\mathrm{CCK} /$ kinase inhibitor is considered (Fig. $5 B$ ). The percentage of cells responding to $\mathrm{CCK}$ in the presence of the PKA inhibitor H89 (52\%) is comparable with that responding to CCK alone (42\%), whereas CCK is relatively ineffective as an inhibitor of potassium currents in the presence of the PKC inhibitor bisindolylmaleimide (16\%). Together, these data agree with the notion that CCK inhibits outward potassium currents by interacting with the CCK-A receptor subtype whose activation stimulates the inositol trisphos- 

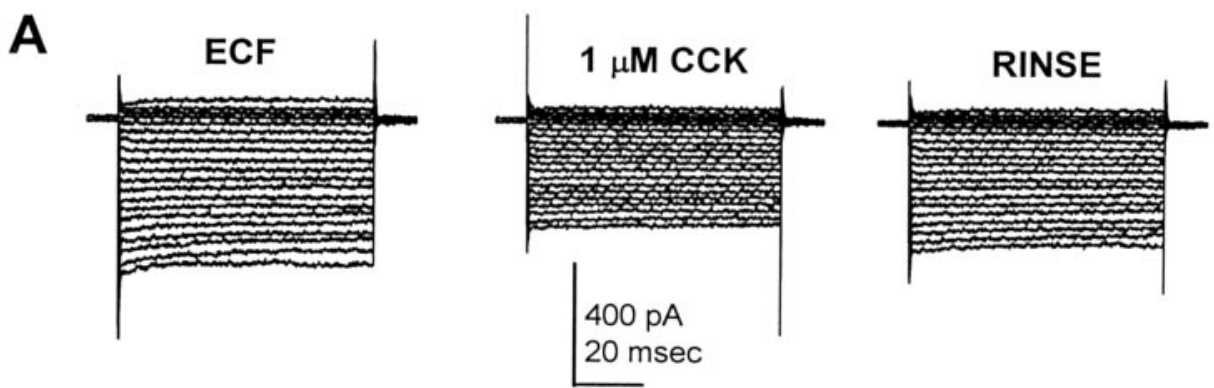

Figure 6. $\mathrm{K}_{\mathrm{IR}}$ is inhibited by exogenous CCK. $A$, A family of inwardly rectifying potassium currents is reversibly reduced in magnitude with the application of $1 \mu \mathrm{M}$ CCK when compared with their previous values $(E C F) . B, \mathrm{~A}$ current-voltage plot of inwardly rectifying potassium current, recorded from a different cell before $(\square)$ or during $(\square)$ exposure to $100 \mathrm{~nm}$ CCK. The current was inhibited at all tested potentials. $C$, Two tested concentrations of CCK were both effective in inhibiting $\mathrm{K}_{\mathrm{IR}}$. The number of responding cells per number of tested cells is presented. Only a subset of taste receptor cells was affected by cholecystokinin. Double asterisks idicate statistical significance $(p<0.01)$.

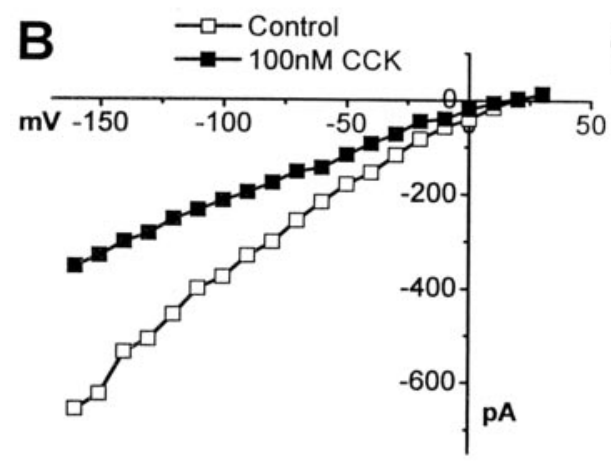

phate/diacylglycerol second messenger system and subsequently PKC, which, in turn, causes a phosphorylation event (presumably on the potassium channel), ultimately reducing the magnitude of the potassium current.

\section{Inwardly rectifying potassium currents are inhibited by CCK}

$\mathrm{K}_{\mathrm{IR}}$ is unique among the ionic conductances that are expressed in taste receptor cells in that it is ubiquitously expressed across cells and is one of the major conductances that contribute to the resting potential (Sun and Herness, 1996). Hence, it is a potentially important current whose inhibition could be responsible, in yet unidentified manners, for the transition of the cell from the resting to an active state. This current has its highest conductance at negative potentials, and, in normal extracellular potassium concentration, its conductance is generally $1-2 \mathrm{nS}$. Because $\mathrm{K}_{\mathrm{IR}}$ is a logical candidate in examining putative effects on electrical excitability, CCK was tested on this conductance to determine whether its application could modify any of the biophysical properties of $\mathrm{K}_{\mathrm{IR}}$. We have demonstrated previously that application of exogenously applied $\mathrm{NE}$, the cAMP analog 8-(4-chlorophenylthio)-cAMP, or the adenylate cyclase activator forskolin was without effect on $\mathrm{K}_{\mathrm{IR}}$ (Herness et al., 2002). To date, only one stimulus, caffeine, has been effective in inhibiting $\mathrm{K}_{\mathrm{IR}}$ (Zhao et al., 2002).

In the present study, $\mathrm{K}_{\mathrm{IR}}$ was isolated by recording in high (100 $\mathrm{mm}$ ) extracellular potassium and holding at the zero current membrane potential. CCK inhibited the magnitude of $\mathrm{K}_{\mathrm{IR}}$ at all tested potentials. Applied at concentrations of either $100 \mathrm{~nm}$ or 1 $\mu \mathrm{M}$, exogenous CCK resulted in a reduction of the magnitude of the recorded current traces (Fig. 6A) without obvious effect on their time course. Representative $\mathrm{K}_{\mathrm{IR}}$ current traces from a single taste receptor cell are presented before, during, and after application of $1 \mu \mathrm{M}$ CCK in Figure $6 A$. Membrane voltage was held at the zero current potential $(-3 \mathrm{mV}$ in this cell), and a series of depolarizing or hyperpolarizing potentials applied in $10 \mathrm{mV}$ increments. Resulting currents were linear and displayed little inactivation. These actions persisted during the application of peptide and were reversed with washout of the peptide from the bathing solution. The current-voltage relationship from a different taste receptor cell is presented in Figure $6 B$ before and during application of $100 \mathrm{~nm} \mathrm{CCK}$. Currents were inhibited at all potentials, and inhibition displayed little voltage dependence.

Summarized data of $\mathrm{K}_{\mathrm{IR}}$ inhibition to two concentrations of cholecystokinin are presented in Figure $6 C$. Current magnitude was measured as evoked by a test pulse from the zero current potential to $-160 \mathrm{mV}$. CCK, when tested at $100 \mathrm{~nm}$, reduced the magnitude of this test pulse to $69 \pm 5 \%$ of its original magnitude ( $n=$ five of seven tested cells) and to $75 \pm 5 \%(n=7$ of 14 tested cells) at $1 \mu \mathrm{M}$ CCK. Inhibitions at both tested concentrations were statistically significant when compared with pretest magnitudes, as indicated by asterisks $(p<0.01)$.

The mechanism of $\mathrm{K}_{\mathrm{IR}}$ inhibition is not known. However, it is known that unlike outward potassium currents, $\mathrm{K}_{\mathrm{IR}}$ is not sensitive to inhibition by cAMP but can be inhibited by G-protein analogues, such as GTP $\gamma$ S (Herness et al., 2002). Because CCK receptors are G-protein coupled, it is possible that inhibition of $\mathrm{K}_{\mathrm{IR}}$ would be expected from activation of the G-protein, perhaps by the $\beta \gamma$ subunit. Inhibition of $\mathrm{K}_{\mathrm{IR}}$ would be expected to depolarize the resting potential.

\section{CCK elevates intracellular calcium levels in a subset of TRCs}

CCK is known to elevate intracellular calcium in a number of cell types via activation of the CCK-A receptor; a well studied example is the pancreatic acinar cell (Williams, 2001). Accordingly, intracellular calcium levels were monitored in dissociated taste receptor cells using a dual-wavelength ratiometric procedure with the calcium sensitive dye fura- 2 before, during, and after application of exogenous CCK. CCK was applied focally to the cell with a steady backstream of ECF. In a subset of tested taste receptor cells, application of exogenous CCK was a highly effective stimulus for elevating intracellular calcium. A sample ratiometric response is illustrated in Figure $7 A$. In this example, a single taste receptor cell was imaged at 340 and 380 excitation 

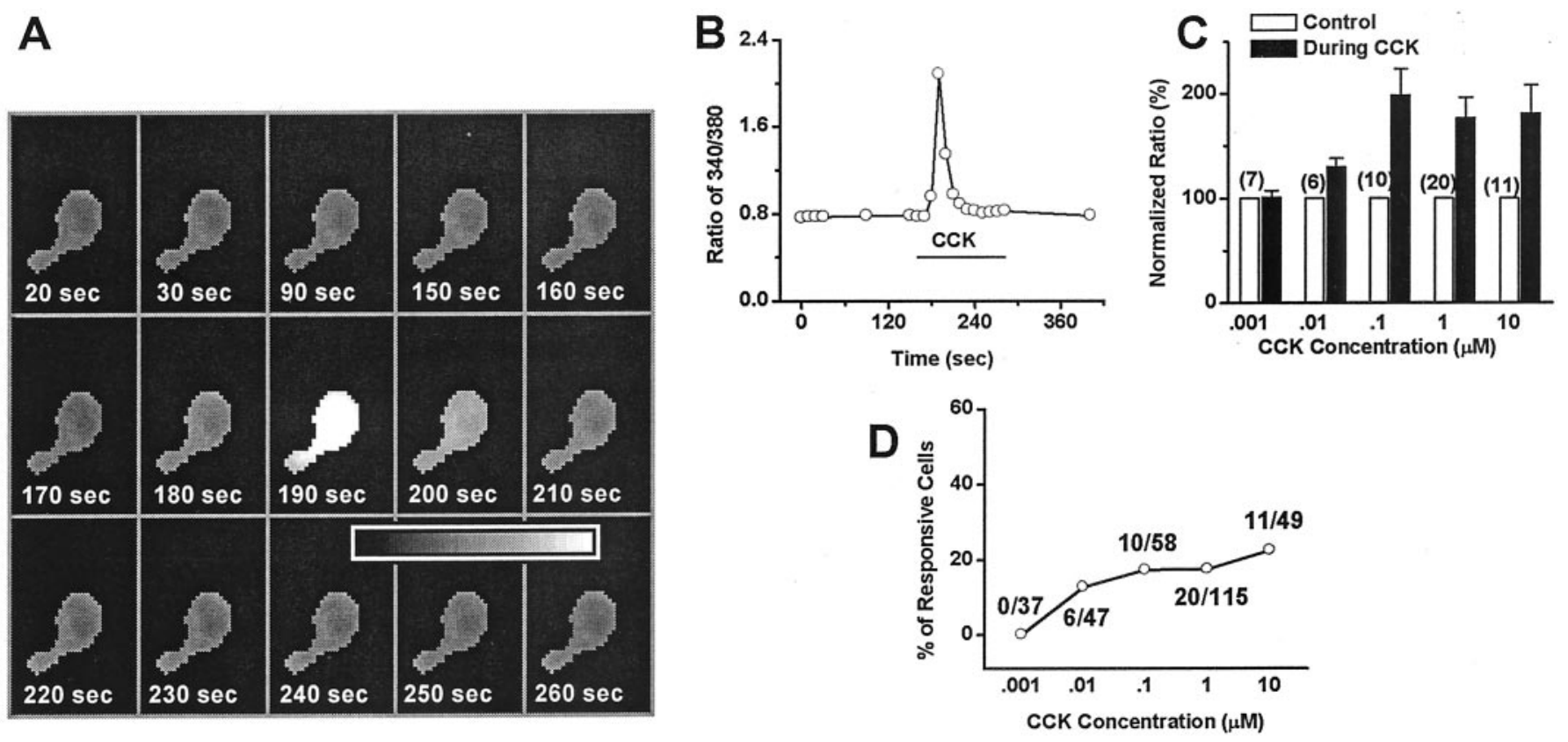

Figure 7. CCK elevates intracellular calcium levels in taste receptor cells. A, A sample response of a single taste receptor cell to CCK is presented using a grayscale applied to the ratio values; light gray indicates high calcium levels. CCK inf usion was started after the 160 sec mark. $B$, Plotted ratio values of the cell responding in $A$. Note that calcium levels begin to fall during the sustained presence of the peptide. $C$, CCK-mediated elevation of intracellular calcium was concentration dependent. Responses to five tested concentrations of CCK are plotted as the peak ratio value during peptide administration (solid bars) normalized to the baseline ratio value. The response magnitude increased sharply after $0.01 \mu \mathrm{M}$. The number of cells contributing to each point is indicated. $D$, The number of cells responding to CCK administration increased with increasing concentration, reaching a plateau value of $\sim 17 \%$ at $0.1 \mu \mathrm{M}$ (number of responding cells per number of tested cells).

wavelengths, the ratio of the emitted light of these two images was determined and background subtracted, and a grayscale applied with dark gray indicating low and light gray indicating high levels of intracellular calcium. Images were taken at the approximate times indicated. CCK application occurred at $160 \mathrm{sec}$. The background corrected ratio of the response in Figure $7 A$ is presented in Figure $7 B$ with the duration of the peptide application marked. Typically, the response characteristics are dynamic, displaying a transient elevation and subsequent diminution of intracellular calcium that occurs even in the sustained presence of peptide. The duration of slow spikes is on the order of several tens of seconds. Often a second application of CCK required a prolonged interstimulus interval (e.g., $20 \mathrm{~min}$ ) to produce a second response of equal magnitude.

Elevations of intracellular calcium induced by cholecystokinin were concentration dependent. Five concentrations of CCK were tested in $\log$ steps ranging from $1 \mathrm{nM}$ to $10 \mu \mathrm{M}$, and ratios, normalized to preapplication values, are presented (Fig. 7C). Concentration dependence of the CCK-induced elevations of intracellular calcium appeared to be steep. Threshold values occurred between 1 and $10 \mathrm{~nm}$, and saturated responses appeared to occur by $100 \mathrm{~nm} \mathrm{CCK}$. The number of cells contributing to each data point is indicated for each concentration. Not all tested cells responded to CCK. Similar to patch-clamp results, the number of responsive cells was a function of concentration (Fig. $7 D$ ). The number of responding cells increased to $\sim 17 \%$ of the tested cells with increasing peptide concentration, with a small increase in the number of responsive cells occurring at $10 \mu \mathrm{M}$.

To determine whether elevations of intracellular calcium were dependent on extracellular or intracellular sources, experiments with calcium-free ECF or thapsigargin, which gradually depletes intracellular calcium stores, were performed. A sample response from a single taste receptor cell to CCK administration in normal and calcium-free ECF is presented in Figure $8 A$. CCK effectively elevated intracellular calcium both before and during exposure to calcium-free ECF without noticeable difference. Summated data are presented in Figure $8 \mathrm{~B}$. CCK alone produced a normalized ratio of $167 \pm 7 \%$ in normal ECF and a normalized ratio of $158 \pm$ $7 \%$ in calcium-free ECF $(n=7)$. These means were not statistically different $(p=0.16)$. Calcium-free ECF $\left(\mathrm{Ca}^{2+}\right.$-free $)$ was without effect on resting intracellular calcium levels $(100 \pm 2 \%)$. However, thapsigargin treatment diminished the calcium response to CCK. A sample response from a different taste receptor cell to $\mathrm{CCK}$ and $\mathrm{CCK}$ in the presence of thapsigargin is presented in Figure $8 C$. Thapsigargin treatment $\left(10^{-6} \mathrm{M}\right)$, which operates by inhibiting the calcium reuptake mechanism on intracellular stores, produced a slow increase in intracellular calcium, which gradually returned to baseline. In the illustrated cell, after the ratio returned to baseline, $\mathrm{CCK}$ was without effect on the measured ratio. Summarized data for thapsigargin treatment in three cells are presented in Figure $8 D$. In these cells, CCK alone produced a ratio of $149 \pm 15 \%$. CCK, after thapsigargin treatment, changed the ratio to $129 \pm 19 \%$, which was similar to the ratio seen for thapsigargin treatment alone, $129 \pm 15 \%$. Thus, changing intracellular stores reduced the response to $\mathrm{CCK}$, whereas elimination of extracellular calcium had no effect on the CCK response.

A similar pharmacological strategy to that applied in the patchclamp experiments was applied to the calcium-imaging experiments with similar results. CCK-evoked elevations of intracellular calcium were prevented by exposure of the cell to $100 \mu \mathrm{M}$ proglumide. A sample response is presented in Figure $9 A$. CCK evoked a large spike-like increase in the fura- 2 ratio. After 20 $\mathrm{min}$, the cell was exposed to proglumide for a period of $12 \mathrm{~min}$. 
Figure 8. CCK-mediated elevation of intracellular calcium is dependent on intracellular but not extracellular calcium stores. $A$, Sample response to CCK administrated in normal or calcium-free ECF. CCK effectively elevates intracellular calcium in either condition. $B$, Pooled data from seven cells for CCK stimulation in normal $(C C K)$ or calcium-free ECF $\left(\mathrm{CCK} / \mathrm{Ca}^{2+}\right.$ free $)$. Calcium-free ECF $\left(\mathrm{Ca}^{2+}\right.$ free $)$ was without effect on intracellular calcium levels $(100 \pm 2 \%)$. C , Sample response from a different cell to CCK or CCK in the presence of thapsigargin, which depletes intracellular calcium stores. Because intracellular stores are depleted with the onset of thapsigargin application, intracellular calcium levels increased. When calcium levels returned to baseline, CCK application was without effect. $D$, Summarized data for thapsigargin treatment in three cells. The CCK response was diminished in the presence of thapsigargin $(C C K / T H A P)$ and was not distinguishable from the thapsigargin alone group (THAP).
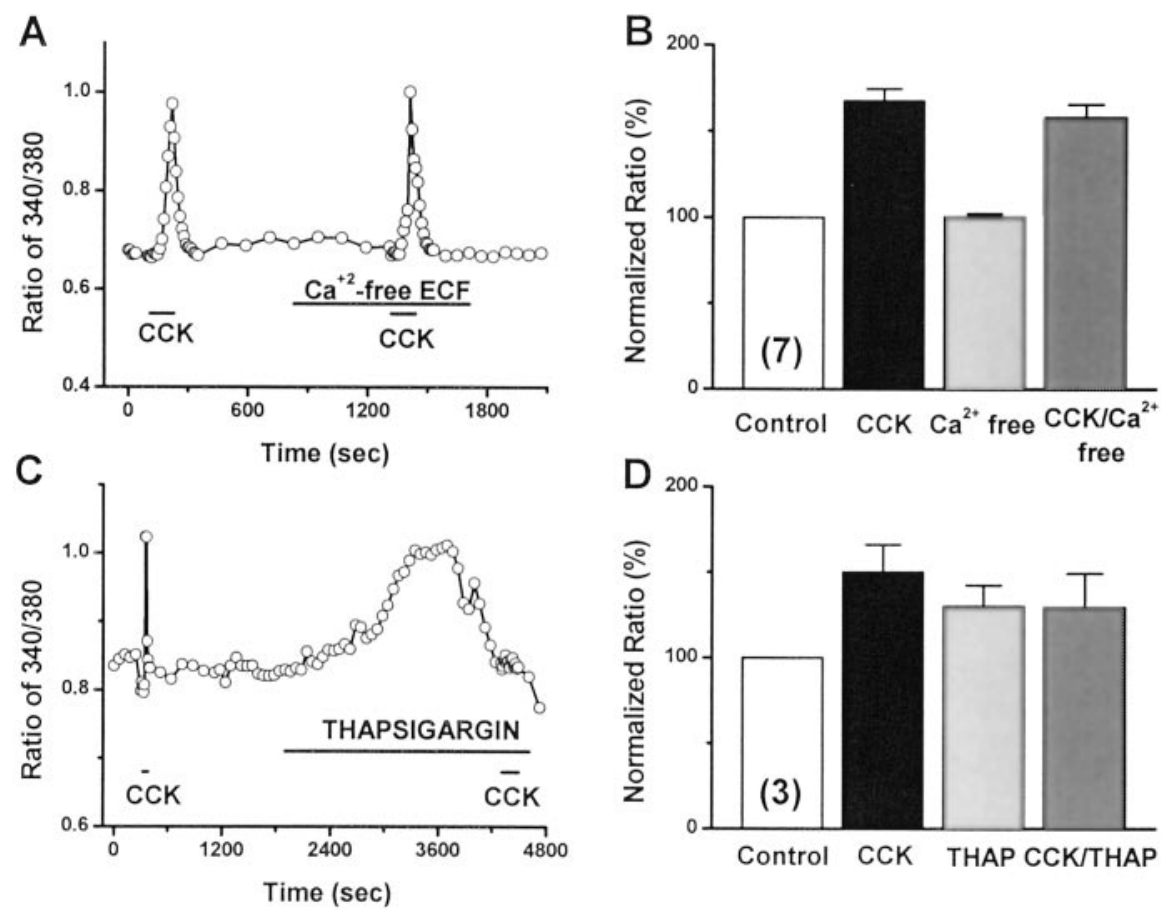

Control CCK THAP CCKITHAP
Proglumide itself was without effect on intracellular calcium. During the proglumide exposure, CCK was reapplied. However, this second application failed to produce a response. As a control, after proglumide exposure, the cell was exposed to $10 \mu \mathrm{M}$ acetylcholine, a robust stimulus for elevating intracellular calcium in taste receptor cells. Acetylcholine, after proglumide exposure, resulted in a profound elevation of intracellular calcium, indicating both an unimpaired ability of the cell to respond to extracellular stimuli and a specificity of proglumide treatment to CCK receptors. Additionally, a third application of CCK evoked a robust response. Summarized data $(n=8)$ for proglumide are presented in Figure $9 B$. CCK produced a mean ratio of $186 \pm$ $14 \%$ before and $103 \pm 2 \%$ during proglumide exposure. These mean values were significantly different from one another $(p<$ 0.001). Proglumide itself was ineffective $(104 \pm 5 \%)$.

The same protocol was applied to lorglumide with very similar results. A sample response (Fig. 9C) illustrates that in a CCKresponsive cell, lorglumide exposure $(0.1 \mu \mathrm{M})$ prevented a subsequent calcium elevation from being induced by a second CCK exposure. However, unlike proglumide, we did not find this effect to be easily reversible, at least within the time frame of our experimental paradigm. A third CCK exposure also failed to influence intracellular calcium levels, although the cell was still responsive to other stimuli that influence intracellular calcium, as indicated by the extremely strong response to $10 \mu \mathrm{M}$ acetylcholine. Summarized data for eight cells (Fig. 9D) indicated that lorglumide completely blocked the CCK response $(118 \pm 8 \%)$ when compared with the control response $(198 \pm 13 \%)$. These mean values were significantly different from one another $(p<$ $0.001)$. Lorglumide itself produced no effect on resting calcium levels $(108 \pm 6 \%)$.

In contrast to these data, the CCK-B receptor antagonist was ineffective in blocking CCK-induced elevations of intracellular calcium. As illustrated in Figure 9E, the response to $100 \mathrm{~nm} \mathrm{CCK}$ was unaltered when presented during L-365,260 exposure when compared with either a previous or subsequent CCK exposure. Summarized data from seven cells are presented in Figure $9 F$.
The CCK-induced ratio was $232 \pm 32 \%$ before L-365,260 exposure and $222 \pm 26 \%$ during the receptor antagonist presentation. There was no statistical difference between these means ( $p=$ 0.279 ).

\section{DISCUSSION}

The localization of the peptide CCK and its mRNA to subsets of taste receptor cells coupled with the demonstration of its physiological actions on these cells strongly serves to establish a novel role for this peptide in peripheral gustatory physiology. To date, there is limited knowledge of peptides in taste receptor cells. Although some peptides have been noted in nerve fibers surrounding taste buds, such as substance $\mathrm{P}$ or calcitonin generelated peptide (Nagy, 1982; Finger, 1986), for the most part, neither peptide expression in taste receptor cells nor functional consequences of peptide actions on these cells have been reported. Two exceptions are vasoactive intestinal polypeptide (VIP) and leptin. VIP has been localized in taste receptor cells of rat and hamster posterior papillae (Herness, 1989b), as well as human circumvallate papillae (Kusakabe et al., 1998), but lacks any functional role at present. Leptin, however, is not expressed in taste receptor cells but may selectively influence sweet taste responses via expression of the leptin receptor on taste receptor cells (Kawai et al., 2000). To our knowledge, the present data are the first to demonstrate both the expression and a functional role for a peptide within the taste bud. Moreover, they additionally confirm the growing notion of cell-to-cell communication within the taste bud established recently for the neurotransmitters serotonin (Herness and Chen, 1997, 2000) and norepinephrine (Herness et al., 2002) and now for the neuropeptide cholecystokinin. Because cotransmission of peptides and classical transmitter is a common neurophysiological motif (Hökfelt et al., 1987; Kupfermann, 1991), the recent demonstrations of the expression and functional consequences of both neurotransmitters and neuropeptides in taste receptor cells may add a new dimension to the understanding of peripheral gustatory processing by including these avenues of communication unrecognized previously as pu- 

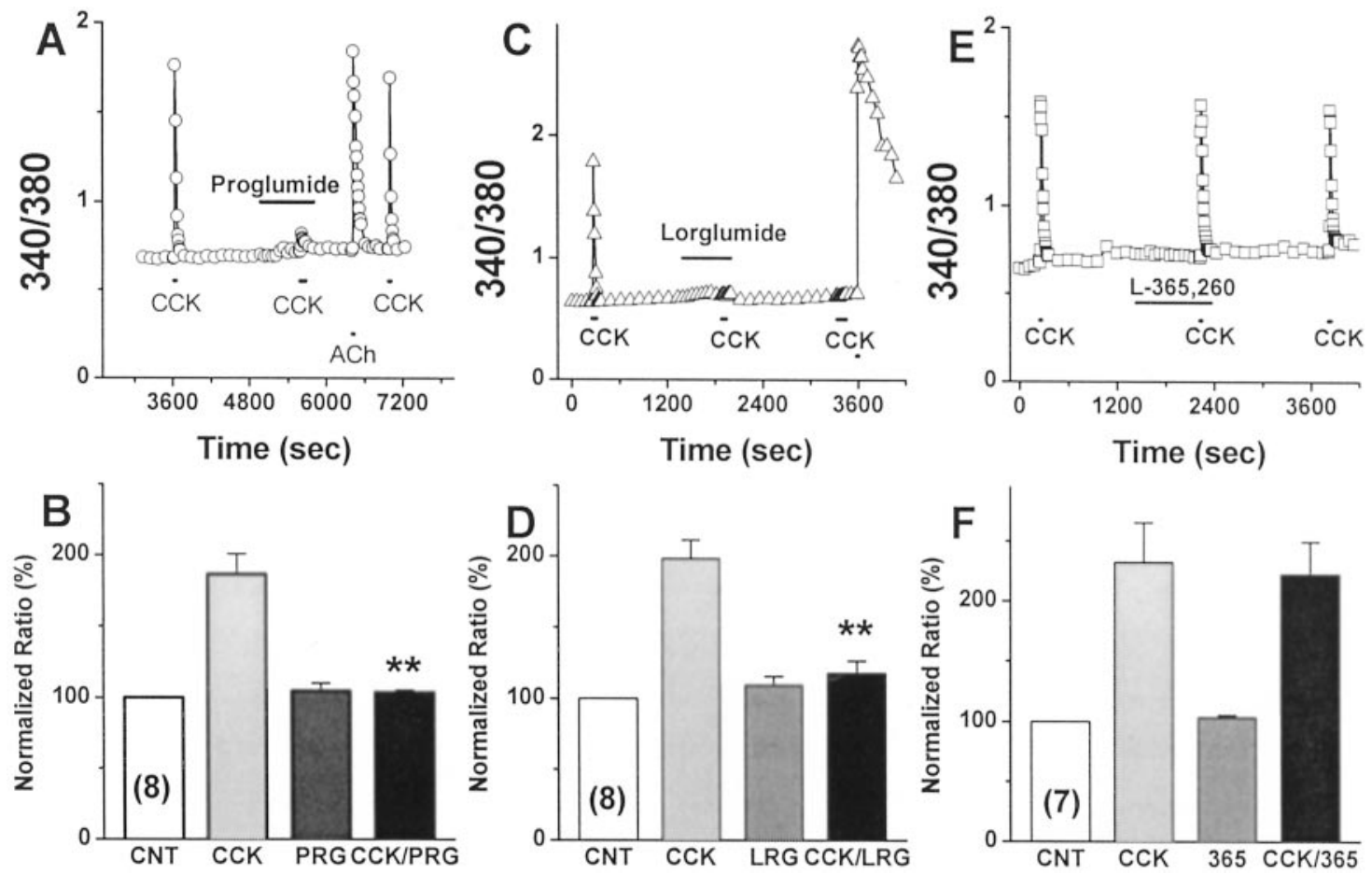

Figure 9. Elevations of intracellular calcium are inhibited by CCK-A but not CCK-B receptor antagonists. Sample responses from three different cells to CCK in the presence of proglumide, a nonspecific CCK receptor antagonist $(A)$; lorglumide, specific for CCK-A receptors $(C)$; or L-365,260, specific for CCK-B receptors $(E)$. Both proglumide and lorglumide blocked CCK-mediated calcium elevations, whereas a clear response is evident in the presence of L-365,260. Summarized data for proglumide (PRG), lorglumide ( $L R G)$, or L-365,260 (365) are presented in $B, D$, and $F$, respectively. $C N T$, Control. The response to CCK (light gray bar) was normalized to baseline values (open bars, number of cells in parentheses). All three antagonists were without effect on ratio values when applied alone (dark gray bars). Mean ratio values of CCK in the presence of either proglumide or lorglumide were statistically different from the mean value of the CCK alone group $\left({ }^{* *} p<0.001\right)$ but not from control values, suggesting a complete block of the responses, whereas mean ratio values of CCK in the presence of L-365,260 were not statistically different from CCK alone $(p=0.28)$, suggesting that this antagonist had no effect on the CCK-induced calcium elevations.

tative mechanisms for such tasks as stimulus identity recognition or quality coding.

\section{Expression patterns of CCK and CCK mRNA}

For the most part, CCK is expressed in only two cell types, endocrine cells of the duodenum (I cells) and peripheral and central neurons (Liddle, 1997), although low-level expression in spermatozoa, adrenal gland, and pituitary has been reported. The robust peptide expression observed in taste receptor cells thus significantly extends this list. In addition to rat, we have also observed taste receptor cells displaying cholecystokinin-like immunoreactivity in posterior fields of hamster and rabbit (our unpublished observations), suggesting that the distribution of the peptide may be common among mammalian taste buds. Interestingly, in a report of a transgenic mouse line produced using the CCK promoter with $\beta$-galactosidase as a reporter gene, a preliminary note of the expression of CCK-lacZ transgene in taste buds was mentioned (Itoh et al., 1998). In contrast, CCK immunoreactivity was observed in basal but not taste receptor cells in the mudpuppy (Welton et al., 1992).

These expression data augment recently developing parallels in the molecular phenotypes of taste receptor cells and cells in the upper GI tract, particularly the antrum and duodenum. Two examples are gustducin, a taste-specific G-protein also expressed in brush cells scattered throughout the surface epithelium of the gut (Höfer et al., 1996), and the recently cloned T2R family of taste receptors, recently reported to be expressed in the antrum and duodenum (Wu et al., 2002). CCK expression in taste recep- tor cells represents a third example of the developing parallel between chemosensitivity of the oral cavity and proximal gut. Additional molecular phenotyping of the CCK-expressing taste receptor cells may provide more insight into their function.

One enigmatic observation of CCK expression in taste receptor cells is the apparent dichotomy between peptide and mRNA expression levels. CCK-expressing taste receptor cells appear to regulate expression in a unique manner (i.e., maintaining robust expression of peptide yet low copy number of mRNA). This expression pattern is in contrast to other cell types, such as neurons or enteroendocrine cells, which express both peptide and mRNA robustly. However, regulation in these two cell types differs. Primary control of CCK expression is exerted at the level of transcription (cf. Hansen, 2001), although post-translation processing of proCCK is well established (Rehfeld and Nielsen, 1995; Beinfeld, 1997). In neurons, expression of CCK mRNA has been reported to be induced by growth factors, cAMP, dopamine, and estrogen, whereas in the intestine, CCK gene expression is primarily regulated by food intake but also by glucocorticoids and pituitary adenylate cyclase-activating peptide. The regulatory element of the rat and human proximal promoter region contains four important elements, one of which is a cAMP response element (CRE)/ phorbol 12-O-tetradecanoate-13 acetate-response element (TRE) region, which could be particularly relevant to taste receptor cells. We have demonstrated recently the presence of CRE-binding protein (CREB) and pCREB in taste receptor cells (Cao et al., 2002). Although pCREB facilitates CCK transcription, activating 
transcription factor-1, interacting with the CRE/TRE region of the promoter, has been shown to repress CCK transcription. At present, no functional connection between pCREB-expressing cells and CCK-expressing cells is known, although this could potentially be an important regulatory element in CCK-expressing taste receptor cells.

\section{Physiological responses of taste receptor cells to CCK}

These data demonstrate that subsets of taste receptor cells respond to exogenous application of physiological concentrations of CCK. At least three actions are documented: (1) inhibition of outward potassium current, (2) inhibition of inwardly rectifying potassium current, and (3) elevations of intracellular calcium. All are excitatory in nature. Hence, potential neuromodulatory actions of CCK during tastant stimulation may be expected to increase the electrical excitability of subsets of taste receptor cells expressing CCK receptors. The nature of this subset of taste receptor cell (e.g., their chemosensitivity) will await future molecular and physiological phenotyping. However, our data thus far suggest CCK-responsive cells to be sensitive to bitter stimuli and colocalize extensively with gustducin (our unpublished observations).

At present, it is not known whether these three reported physiological actions of CCK occur within the same individual cell or whether they are segregated among the subset of CCKresponsive taste receptor cells. All appear to be mediated by the same receptor subtype, the CCK-A receptor, which typically funnels into inositol trisphosphate and diacylglycerol production (Williams, 2001). In taste receptor cells, activation of this second messenger system has been linked to both inhibition of potassium currents and elevations of intracellular calcium. The inhibition of outward potassium currents by bitter stimuli may be blocked by bisindolylmaleimide (our unpublished observations), and the present data with bisindolylmaleimide and H89 support the notion that stimulation of CCK-A receptors in taste receptor cells operates via PKC rather than PKA. Moreover, elevations of intracellular calcium are clearly consistent with inositol trisphosphate production, and taste receptor cells express $\mathrm{IP}_{3}$ receptors (Clapp et al., 2001). Collectively, these observations suggest that all required pathways for inhibition of potassium currents and elevations of intracellular calcium could be coexpressed within the same cell.

If these actions do occur in the same cell, it is not known whether they would be sequential or parallel events. Actions on electrical excitability might serve to depolarize the membrane potential and activate the $\mathrm{IP}_{3} / \mathrm{DAG}$ system, events that could subsequently produce elevations of intracellular calcium levels. A similar mechanism of cholecystokinin-producing depolarization via suppression of a potassium conductance has been reported in rat thalamic neurons (Cox et al., 1995). Such membrane depolarization could also be expected to result in subsequent activation of voltage-gated calcium channels. However, our results suggest that CCK-induced elevations of intracellular calcium depend solely on intracellular rather than extracellular sources. Two observations may explain this paradox. First, voltage-gated calcium channels are not ubiquitously expressed in taste receptor cells. Second, more cells respond with inhibitions of potassium current than do when tested for intracellular calcium levels. Hence, our observations to date suggest that subsets of CCKresponsive taste receptor cells may exist.

Additionally, these physiological actions of CCK observed at the single-cell level are unlikely to occur in isolation but are expected to occur simultaneously with other modulatory actions at the level of the taste bud during gustatory stimulation. The specialized cloistered arrangement of taste receptor cells into buds has long been speculated as an optimal anatomical arrangement for cell-to-cell communication, and mounting physiological data for such communication are accumulating. Within the mammalian taste bud, physiological actions of neurotransmitters on taste receptor cells have been demonstrated recently, providing strong evidence for communication between cells. Rat circumvallate and foliate taste receptor cells respond to exogenous application of serotonin (Herness and Chen, 1997) with an inhibition of a calcium-activated potassium current. This inhibition is mimicked by 5-HT1A receptor subtype agonists (Herness and Chen, 2000) and would be expected to reduce the adaptation rate of action potential firing. Additionally, rat taste receptor cells respond to glutamate via glutamate receptors (Chaudhari et al., 1996; Bigiani et al., 1997; Lin and Kinnamon, 1999; Caicedo et al., 2000a,b) that are separate from the role of glutamate as the stimulus underlying the umami sensation (Chaudhari et al., 1996). A third example in the rat taste bud is norepinephrine. Taste receptor cells express both $\alpha$ and $\beta$ adrenergic receptors and respond with an inhibition of potassium current, augmentation of a chloride current, and elevations of intracellular calcium (Herness and Sun; 1999; Herness et al., 2002). The observation that taste receptor cells respond to neurotransmitters adds a new dimension to the classic linear view of taste receptor cells releasing transmitter solely to excite the afferent nerve (cf. Getchell, 1997).

There are preliminary suggestions within the literature for CCK effects in peripheral taste physiology. In one, CCK increased $\mathrm{NaCl}$-induced chorda tympani activity (Serova and Esakov, 1985), whereas in the other, there was a modest increase in sucrose responses without effect on the $\mathrm{NaCl}$ response (Gosnell and Hsiao, 1984). How potential modulatory actions of CCK may affect the neural output remains to be determined.

\section{REFERENCES}

Adler E, Hoon MA, Mueller KL, Chandrashekar J, Ryba NJP, Zuker CS (2000) A novel family of mammalian taste receptors. Cell 100:693-702. Beinfeld MC (1997) CCK biosynthesis and processing: recent progress and future challenges. Life Sci 61:2359-2366.

Bigiani A, Delay RJ, Chaudhari N, Kinnamon SC, Roper SD (1997) Responses to glutamate in rat taste cells. J Neurophysiol 77:3048-3059.

Caicedo A, Kim K-N, Roper SD (2000a) Glutamate-induced cobalt uptake reveals non-NMDA receptors in rat taste cells. J Comp Neurol 417:315-324.

Caicedo A, Jafri MS, Roper SD (2000b) In situ $\mathrm{Ca}^{2+}$ imaging reveals neurotransmitter receptors for glutamate in taste receptor cells. J Neurosci 20:7978-7985.

Cao Y, Shreffler C, Herness S (2002) Localization and functional investigation of transcription factor CREB in taste receptor cells. NeuroReport 13:1321-1325.

Chandrashekar J, Mueller KL, Hoon MA, Adler E, Feng L, Guo W, Zuker CS, Ryba NJ (2000) T2Rs function as bitter taste receptors. Cell 100:703-711.

Chaudhari N, Yang H, Lamp C, Delay E, Cartford C, Than T, Roper S (1996) The taste of monosodium glutamate: membrane receptors in taste buds. J Neurosci 16:3817-3826.

Chaudhari N, Landin MA, Roper SD (2000) A metabotropic glutamate receptor variant functions as a taste receptor. Nat Neurosci 3:113-119.

Clapp TR, Stone LM, Margolskee RF, Kinnamon SC (2001) Immunocytochemical evidence for co-expression of type III $\mathrm{IP}_{3}$ receptor with signaling components of bitter taste transduction. BMC Neurosci 2:6.

Cox CL, Huguenard JR, Prince DA (1995) Cholecystokinin depolarizes rat thalamic reticular neurons by suppressing a $\mathrm{K}^{+}$conductance. J Neurophysiol 74:990-1000.

Finger TE (1986) Peptide immunohistochemistry demonstrates multiple classes of perigemmal nerve fibers in the circumvallate papillae of the rat. Chem Sens 11:135-144.

Getchell TV (1997) Communication within the bud. A commentary on the paper by Scott Herness and Yusche Chen. NeuroReport 8:iii.

Gilbertson TA, Damak S, Margolskee RF (2000) The molecular physiology of taste transduction. Curr Opin Neurobiol 10:519-527. 
Gosnell BA, Hsiao S (1984) Effects of cholecystokinin on taste preference and sensitivity in rats. Behav Neurosci 98:452-460.

Hansen TVO (2001) Cholecystokinin gene transcription: promoter elements, transcription factors and signaling pathways. Peptides 22:1201-1211.

Herness MS (1989a) A dissociation procedure for mammalian taste cells. Neurosci Lett 106:60-64.

Herness MS (1989b) Vasoactive intestinal peptide (VIP)-like immunoreactivity in rodent taste cells. Neuroscience 33:411-419.

Herness MS, Chen Y (2000) Serotonergic agonists inhibit calciumactivated potassium and voltage-dependent sodium currents in rat taste receptor cells. J Membr Biol 173:127-138.

Herness MS, Sun X-D (1995) Voltage-dependent sodium currents recorded from dissociated rat taste cells. J Membr Biol 146:73-84.

Herness MS, Sun X-D (1999) Characterization of chloride currents and their noradrenergic modulation in rat taste receptor cells. J Neurophysiol 82:260-271.

Herness S (2002) Researching isolated taste receptor cells: deciphering transduction cascades with patch-clamp and calcium-imaging techniques. In: Methods and frontiers in neuroscience: methods in chemosensory research (Simon SA, Nicolelis MA, eds), pp 169-206. Boca Raton, FL: CRC

Herness S, Chen Y (1997) Serotonin inhibits calcium-activated $\mathrm{K}^{+}$current in rat taste receptor cells. NeuroReport 8:3257-3261.

Herness S, Gilbertson T (1999) Cellular mechanisms of taste transduction. Annu Rev Physiol 61:873-900.

Herness S, Zhao FL, Lu SG, Kaya N, Shen T, Sun XD (2002) Adrenergic signaling among rat taste receptor cells. J Physiol (Lond) 543:601-614

Höfer D, Püschel B, Drenckhahn D (1996) Taste receptor-like cells in the rat gut identified by expression of $\alpha$-gustducin. Proc Natl Acad Sci USA 93:6631-6634.

Hökfelt T, Millhorn D, Scroogy K, Tsuruo Y, Ceccatelli S, Lindt B, Meister B, Melander T, Schalling M, Bartfai T, Terenius L (1987) Coexistence of peptides with classical neurotransmitters. Experientia 43:768-780.

Hoon MA, Adler E, Lindemeier J, Battey JF, Ryba NJP, Zuker CS (1999) Putative mammalian taste receptors: a class of taste-specific GPCRs with distinct topographic selectivity. Cell 96:541-551.

Itoh Y, Kozakai I, Toyomizu M, Ishibashi T, Kuwano R (1998) Mapping of cholecystokinin transcription in transgenic mouse brain using Escherichia coli $\beta$-galactosidase reporter gene. Dev Growth Differ 40:395-402.

Kawai K, Sugimoto K, Nakashima K, Miura H, Ninomiya Y (2000) Leptin as a modulator of sweet taste sensitivities in mice. Proc Natl Acad Sci USA 97:11044-11049.

Kim DJ, Roper SD (1995) Localization of serotonin in taste buds: a comparative study in four vertebrates. J Comp Neurol 353:364-370.

Kupfermann I (1991) Functional studies of cotransmission. Physiol Rev $71: 683-732$.

Kusakabe T, Matsuda H, Gono Y, Furukawa M, Hiruma H, Kawakami T, Tsukuda M, Takenaka T (1998) Immunohistochemical localisation of regulatory neuropeptides in human circumvallate papillae. J Anat 192:557-564

Liddle RA (1997) Cholecystokinin cells. Annu Rev Physiol 59:221-242.

Lin W, Kinnamon SC (1999) Physiological evidence for ionotropic and metabotropic glutamate receptors in rat taste cells. J Neurophysiol 82:2061-2069.
Lindemann B (2001) Receptors and transduction in taste. Nature 413:219-225.

Margolskee RF (2002) Molecular mechanisms of bitter and sweet taste transduction. J Biol Chem 277:1-4

Matsunami H, Montmayeur JP, Buck LB (2000) A family of candidate taste receptors in human and mouse. Nature 404:601-604

Miyasaka K, Masuda M, Funakoshi A (1997) Regulation of cholecystokinin release and transcription in a rat without gene expression of cholecystokinin-A receptor. Digestion 58:104-110.

Montmayeur J-P, Liberles SD, Matsunami H, Buck LB (2001) A candidate taste receptor gene near a sweet taste locus. Nat Neurosci 4:492-498

Nagy JI (1982) The nature of the substance P containing nerve fibers in taste papillae of the rat tongue. Neuroscience 7:3137-3151.

Nelson G, Hoon MA, Chandrashekar J, Zhang Y, Ryba NJP, Zuker CS (2001) Mammalian sweet taste receptors. Cell 106:381-390.

Nelson G, Chandrashekar J, Hoon MA, Feng L, Zhao G, Ryba NJP, Zuker CS (2002) An amino-acid taste receptor. Nature 416:199-202.

Obata H, Shimada K, Sakai N, Saito N (1997) GABAergic neurotransmission in rat taste buds: immuno-cytochemical study for GABA and GABA transporter subtypes. Brain Res Mol Brain Res 49:29-36.

Ogura T (2002) Acetylcholine increases intracellular $\mathrm{Ca}^{2+}$ in taste cells via activation of muscarinic receptor. J Neurophysiol 87:2643-2649.

Pumplin DW, Yu C, Smith DV (1997) Light and dark cells of rat vallate taste buds are morphologically distinct cell types. J Comp Neurol 378:389-410.

Rehfeld JF, Nielsen FC (1995) Molecular forms and regional distribution of cholecystokinin in the central nervous system. In: Cholecystokinin and anxiety: from neuron to behavior (Bradwejn J, Vassar E, eds), pp 33-36. Heidelberg: Springer.

Ren Y, Shimada K, Shirai Y, Fujimiya M, Saito N (1999) Immunocytochemical localization of serotonin and serotonin transporter (SET) in taste buds of rat. Brain Res Mol Brain Res 74:221-224.

Serova ON, Esakov AI (1985) Activating effect of cholecystokininpancreozymin on the taste receptor system on the rat. Fiziol Zh SSSR Im I M Sechenova 71:1271-1277.

Shimizu K, Kato Y, Shiratori K, Ding Y, Song Y, Furlanetto R, Chang TM, Watanabe S, Hayashi N, Kobayashi M, Chey WY (1998) Evidence for existence of CCK-producing cells in rat pancreatic islets. Endocrinology 139:389-396.

Sun X-D, Herness S (1996) Characterization of inwardly-rectifying potassium currents from dissociated rat taste receptor cells. Am J Physiol 271:C1221-C1232.

Welton J, Taylor R, Porter AJ, Roper SD (1992) Immunocytochemical survey of putative neurotransmitters in taste buds from Necturus maculosus. J Comp Neurol 324:509-521.

Williams JA (2001) Intracellular signaling mechanisms activated by cholecystokinin-regulating synthesis and secretion of digestive enzymes in pancreatic acinar cells. Annu Rev Physiol 63:77-97.

Williams JA, Blevins GT (1993) Cholecystokinin and regulation of pancreatic acinar cell function. Physiol Rev 73:701-723.

Wu SV, Rozengurt N, Yang M, Young SH, Sinnett-Smith J, Rozengurt E (2002) Expression of bitter taste receptors of the T2R family in the gastrointestinal tract and enteroendocrine STC-1 cells. Proc Natl Acad Sci USA 99:2392-2397.

Zhao FL, Lu SG, Herness S (2002) Dual actions of caffeine on voltagegated ionic currents and intracellular calcium in rat taste receptor cells. Am J Physiol 283:R115-R129. 